\title{
Preliminary Data on Life Cycle of Creophilus maxillosus Linnaeus (Coleoptera: Staphylinidae) and New Report of this Species on a Human Corpse, South of Iran
}

Keshavarzi D ${ }^{1}$, Fereidooni $\mathrm{M}^{2 *}$, Moemenbellah-Fard MD, Nasiri $\mathrm{Z}^{1}$, Soltani $\mathrm{Z}^{1}$, Dabaghmanesh $\mathrm{T}^{1}$, Montazeri $\mathrm{M}^{2}$

${ }^{1}$ Department of Medical Entomology and Vector Control, Research Centre for Health Sciences, School of Health, Shiraz University of Medical Sciences, Iran.

${ }^{2}$ Shiraz Institute of Legal Medicine, Shiraz, Iran.

\begin{abstract}
Beetles (Coleoptera) have been recognized as significant entomological evidence in the forensic entomology field in estimating the postmortem interval (PMI). We report on the colonization of an adult human corpse by three beetle species in Sadra district, Fars province, south of Iran. The adults of Creophilus maxillosus, Dermestes frischii and Hister sp were all collected from the victim's body which had been wrapped in a sack. For the life cycle study, Creophilus maxillosus (Coleoptera: Staphylinidae) adult beetles were allowed to feed, mate and oviposit in rearing chamber $(11 \times 9 \mathrm{~cm})$ at $23 \pm 1{ }^{\circ} \mathrm{C}$. Development rates from the instance mates placed together to the emergence of adults was 41 days. Information from this study can be helpful in forensic entomology study.
\end{abstract}

Keywords: Forensic Entomology; Creophilus Maxillosus; Life Cycle; Iran.

\section{*Corresponding Author:}

Fereidooni M,

Shiraz Institute of Legal Medicine, Modarres St., P.O. Box: 71546-75891,

Shiraz, Iran.

Tel: +980937858 8308

Fax: +98 07132342697

E-mail: Forensicentomology@ yahoo.com

Received: May 11, 2015

Accepted: June 30, 2015

Published: July 08, 2015

Citation: Fereidooni M et al., (2015) Preliminary Data on Life Cycle of Creophilus maxillosus Linnaeus (Coleoptera: Staphylinidae) and New Report of this Species on a Human Corpse, South of Iran. Int J Forensic Sci Pathol. 3(7), 144-147. doi: http://dx.doi.org/10.19070/2332287X-1500035

Copyright: Fereidooni $\mathbf{M}^{\odot}$ 2015. This is an open-access article distributed under the terms of the Creative Commons Attribution License, which permits unrestricted use, distribution and reproduction in any medium, provided the original author and source are credited.

\section{Introduction}

Forensic entomology is the application of the study of arthropods to legal issues, the study of beetles is important in forensic entomology, this can be helpful in determining the time of death or post mortem interval (PMI) [1]. Two major groups of insects are predictably attracted to corpse and provide useful information in forensic investigation; the flies and the beetles [2].

The order Coleoptera contains a number of forensically significant families, namely Staphylinidae, Nitidulidae, Scarabaeidae, Silphidae, Dermestidae, and Histeridae [3]. Staphylinidae beetles (rove beetles) are a family of insects in the suborder Polyphaga of the order Coleoptera (beetles), this order is distinct from others by the presence of a pair of hardened and thickened wings or "elytra" that leave more than half of their abdomen exposed [4]. The Staphylinidae are widespread beetle family With approximately 58,000 species in thousands of genera, the group is currently recognized as the largest family of beetles. Most rove beetles are predators of insects and other kinds of invertebrates, living in forest leaf litter and similar kinds of decaying plant matter [5]. Staphylinidae adult beetles are variable in size, 15 to 22 $\mathrm{mm}$. The large size and stout build, coupled with the distinctive pattern of creamy grey hairs on an otherwise dark body will identify this beetle, the shiny thorax is free from hairs [6].

Adults of this family are active throughout the year, they are probably the most common predators found on corpses and are highly abundant on cadavers [7]. For these reasons they may be useful for forensic entomology. The most commonly reported and forensically important species of Staphylinidae is hairy rove beetle - Creophilus maxillosus (Figure 1). It was found to be highly useful for succession-based PMI estimations [8, 9]. Habitat and seasonal associations of necrophilous Staphylininae may provide forensically valuable information and could be good candidates for indicators of season of death or corpse relocation [10].

The application of the entomological method to determine the time of death consists of two main procedures; the estimate based on the oldest individuals that have developed on the body (minimum PMI) and estimate based on the successional patterns [3]. Depending on species and ambient air temperature this development needs up to several weeks. Insects colonize the corpse in a predictable regularity; as beetles are found in the late stages of body decomposition [1]. Therefore, they are useful in the estimation of the minimum postmortem interval (PMI min). Some Staphylinidae species were found in human corpse and cadavers 
Figure 1. C. maxillosus adult in dorsal view.

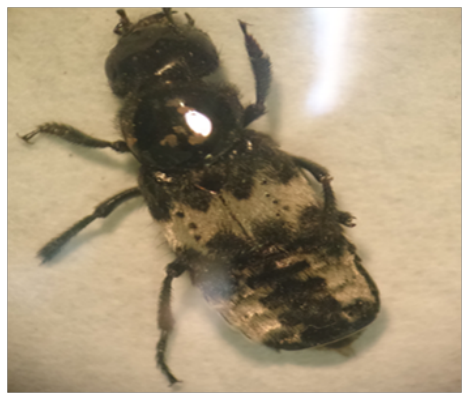

of animals in the last stages of decay in different regions [11-13].

Studies on the developmental rates of forensic insects are usually conducted in the laboratory under constant temperatures and relative humidity and the knowledge of the development time of insect species at different temperatures can provide reliable evidence for the determination of PMI in legal medicine [2]. There is a lack of knowledge of life cycles of Staphylinidae, particularly of species of forensic importance. The aim of this study was to produce life-table data on Creophilus maxillosus for the first time in Iran. The first entomology study on the human corpse in Iran was conducted by Keshavarzi who found a beetle species from a human corpse in Shiraz in 2015 [14]. However, this report is the first report of this species on a human corpse in Iran.

\section{Materials and Methods}

The adults of Creophilus maxillosus, Dermestes frischii and Hister sp were collected from a human corpse in Fars province, in Iran $\left(29.62^{\circ} \mathrm{N}, 52.53^{\circ} \mathrm{E}\right)$ and taken to Shiraz Institute of Legal Medicine on 1th, June 2015. Shiraz is the capital of Fars Province, located in the southern part of the country. There are three distinct climatic regions in this province. This province has moderate temperature in winter and very hot weather in summer.

The cause of death was homicide. The time of death was estimated to have been 2-3 days before the discovery of the body based on the medical examination (rigor mortis and putrefaction stage) (Figure 2). The corpse was in the bloat stage of decay and placed in a sack in the field. Adult beetles were collected from the underside of the body in place of crime by the second author at $23 \mathrm{pm}$.

The adults of C. maxillosus for study on life cycle were collected from a rat carrion (Rattus norvegicus, Berkenhout) on November 2014. Rat carcasses were exposed in an old room $\left(6 \mathrm{~m}^{2}\right)$ of a house in the Fars province, Iran. Once in the lab a total of $4 C$. maxillosus adults of both sexes were placed inside a plastic container measuring $11 \times 9 \mathrm{~cm}$ and filled with approximately $3 \mathrm{~cm}$ of dry wood chips and sand. To provide protection and a source of humidity and water, we introduced a piece of cotton soaked with distilled water. Semi-dry beef meat and live larvae of Sarcophaga sp were supplied as a food source.

The colonies were maintained for one generation in a thermostatic room with $23 \pm 1^{\circ} \mathrm{C}$ temperature, 12:12 light and dark period and $58 \pm 2 \%$ of relative humidity. Recording the time required for larval stage developments and pupation was performed at every four-hour intervals. Several different keys were used to diagnostic the family and species $[15,16]$.

\section{Results}

In this study three species of beetles were collected on a human corpse, distributed in 3 families (Histeidae, Dermestidae and Staphylinidae). They were identified by family and species, whenever possible. These species were C. maxillosus, D. frischii and Hister $s p$. The most abundant species was C. maxillosus $(\mathrm{n}=13)$, followed by Hister sp $(\mathrm{n}=6)$ and $D$. frischii $(\mathrm{n}=4)$.

Life cycle duration of C. maxillosus was determined for one generation. In this study we obtained some preliminary results of the life cycle of C. maxillosus under controlled conditions in laboratory. Life cycle from adult to adult stage of this species were 41 days. 12 days after the adults were placed together, the first larval stage appeared. Development rates from larval stage to pupariation were 15 days and development period from pupariation to emergence were 14 days.

\section{Description of $C$. maxillosus adult}

Adults: body and hairs black with exception the some pubescences white on anterior angles of pronotum, gray hairs on elytra and abdomen. Body length 15-19 mm; head bare except for the temples; antennae short, the last five flagellomeres forming a club and broader than long; pronotum bare except narrowly on the side margins, disc of pronotum glabrous without punctures; white pu-

\section{Figure 2. The male human corpse.}

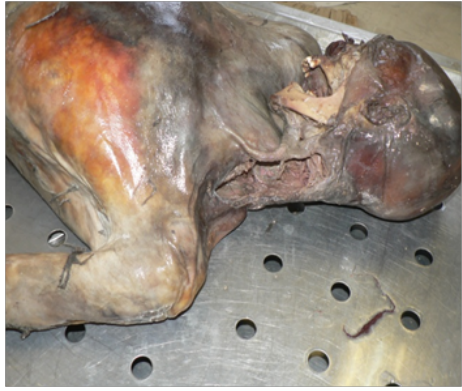


bescence on the anterior angles of the pronotum; elytra covered with short dense hairs forming a broad irregular transverse gray band across them, exposed part of abdomen also with thick variegated gray hairs [17].

\section{Description of $D$. frischii adult}

The Dermestes frischii which belongs to the Dermestes genus, is differentiated from other genera by the absence of a median ocellus on front head and the presence of a pair of compound eyes, hind wings and a scutellum. The Dermestes frischii adult can be distinguished from other species in Dermestidae family by the small black spots at each side on the sternite; also the last sternite has a median blackish spot on its rear border, which does not extend to the front border of the sternite [14].

\section{Description of Hister genus adult}

Species in this genus are commonly 4 to $5 \mathrm{~mm}$ in length and are worldwide in distribution (Figure 3). Their body color is most frequently a shiny jet black, but in some species can be brown, red, or metallic green. The body shape is very convex in profile, and the elytra is short and cut square at the apex, exposing the last two abdominal segments [2].

\section{Discussion}

C. maxillosus considered as a species of forensic importance in the world for season of death and corpse relocation. [18-21]. C. maxillosus was the most frequently observed species among Staphylinidae in forensically studies $[4,9,10]$. The presence of beetles is varied with the decomposition stage of the corpse or carcass, although the larvae are present and often abundant during the later stages of decomposition, the adults may arrive very early, often within the first 24 hours after death. During this early arrival the adults will feed on the eggs and newly hatched larvae of flies [1]. So in our study, the absence of Diptera larvae on the body can be due to the presence of predators (C. maxillosus). In our study the $D$. frischii adults observed in the bloat stage, similar finding were reported by Yones, that reported the Dermestes frischii adults on human leftover parts at all decomposition stages (fresh, bloat and dry stage) [3]. This species was collected in the active decay stage (days 2-8), advanced decay (days 8-13) and dry stage also (days 13-21) [23, 14]. In contrary to our report, Hister genus reported by Vitta in the advanced decay and dry stage of body decomposition [24].

The study on the biology of the genus C. maxillosus is scarce. According to the results of the Erin study [25] mean total developmental times for C. maxillosus at 16,24 , and $32^{\circ} \mathrm{C}$ were $1,523.3$,

\section{Figure 3. Hister sp adult in dorsal view.}

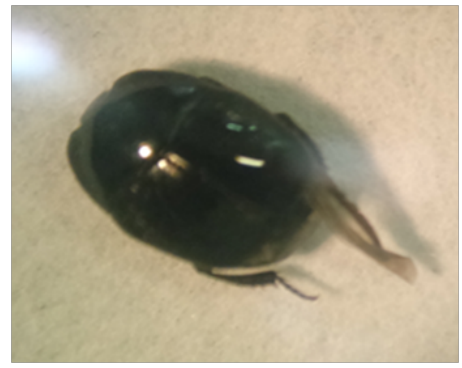

857.8, and 571.3 hours, respectively, while in the present study development rates for $C$. maxillosus at $23 \pm 1^{\circ} \mathrm{C}$ temperature from the instance mates placed together to the emergence of adults was 41 days.

According to the Kramer study [26], the first instar larvae were seen 9 days after the adults were placed in the rearing jar. While in present study 12 days after the adults were placed together, the first larval stage appeared.

The study on the life cycle of insect with forensic importance is important and plays a crucial role in forensic entomology for post mortem interval determination [2]. This publication provides the first data on its rearing in controlled conditions in Iran. In life table studies under field conditions, many factors can influence on their survival and developmental rates [27]. Therefore, further studies on beetles species are needed to use these species in forensic investigation.

\section{Acknowledgments}

The authors would like to appreciate for collaboration of the Shiraz Institute of Legal Medicine.

\section{References}

[1]. Catts EP, Goff ML (1992) Forensic entomology in criminal investigations. Annu Rev Entomol 37:253-272.

[2]. Byrd JH, Castner JL (2009) Forensic Entomology: The Utility of Arthropods in Legal Investigations, Boca Raton: CRC Press.

[3]. Yones DA, Attia RA, Galal LA, Hameed SY (2010) Identification of forensically important beetles on exposed human left over parts in Assuit, Egypt during spring/ summer. Assiut Medicine Journal 34: 123-130.

[4]. Matuszewski S, Bajerlein D, Konwerski S, Szpila K (2008) An initial study of insect succession and carrion decomposition in various forest habitats of Central Europe. Forensic Sci Int 180(2-3):61- 69.

[5]. Samin N, Zhou H, Imani S, Rastegar J (2011) A contribution to the knowledge of Iranian Staphylinidae (Coleoptera: Staphylinoidea). Archives of Biological Sciences 63(4):1235-1243.

[6]. Newton AF (2007) Documenting biodiversity: how well are we doing in Staphyliniformia? (Coleoptera). Entomological Society of America poster presentation.

[7]. Smith KG (1986) A Manual of Forensic Entomology, The Trustees of British Museum (Natural History) London.

[8]. Battán Horenstein M, Linhares AX (2011) Seasonal composition and temporal succession of necrophagous and predator beetles on pig carrion in central Argentina. Medical and veterinary entomology 25(4):395-401.

[9]. Matuszewski S, Bajerlein D, Konwerski S, Szpila K (2010) Insect succession and carrion decomposition in selected forests of Central Europe. Part 2: Composition and residency patterns of carrion fauna. Forensic Science International 195(1):42-51.

[10]. Madra A, Szymon K, Szymon M (2014) Necrophilous Staphylininae (Coleoptera: Staphylinidae) as indicators of season of death and corpse relocation. Forensic Science International 242: 32-37. 
[11]. Segura NA, Usaquén W, Sánchez MC, Chuaire L, Bello F (2009) Succession pattern of cadaverous entomofauna in a semi-rural area of Bogoté, Colombia. Forensic Sci Int 187(1-3):66-72.

[12]. Arnaldos MI, Romera E, Presa JJ, Luna A, Garcia MD (2004) Studies on seasonal arthropod succession on carrion in the southeastern Iberian Peninsula. Int J Legal Med 118(4):197-205.

[13]. Prado C, García MDG, Serrano A, Hidalgo PG, Outerelo R (2010) Staphylinid forensic communities from Lisbon with new records for Portugal (Coleoptera: Staphylinidae). Boln Asoc esp Ent 34(1):87-98.

[14]. Keshavarzi D, Moemenbellah-Fard MD, Fereidooni M, Montazeri M (2015) First Report of Dermestes frischii Kugelann (Coleoptera: Dermestidae) on a Human Corpse, South of Iran. Int J Forensic Sci Pathol 3(4):113-115.

[15]. Brunke A, Newton A, Klimaszewski J, Majka C, Marshall S (2011) Staphylinidae of Eastern Canada and adjacent United States. Key to subfamilies; Staphylininae: Tribes and Subtribes, and species of Staphylinina. Canadian Journal of Arthropod Identification 12: 1-110.

[16]. Cameron M (1930) The fauna of British India including Ceylon and Burma (Coleoptera: Staphylinidae). Taylor and Francis, London. 1:650.

[17]. Augul RS, Al-Saffar HH, Ali HB, Rassoul MA (2015) First Record of Hairy Rove Beetle, Creophilus maxillosus (Linnaeus, 1758) (Coleoptera; Staphylinidae) for Iraq. Int J Curr Microbiol App Sci 4(4):82-85.

[18]. Benecke M (1998) Six forensic entomology cases: description and commentary. J Forensic Sci 43(4):797-805.

[19]. Picard CJ, Wells JD (2012) A test for carrion fly full siblings: a tool for detecting postmortem relocation of a corpse. J Forensic Sci 57(2):535-538.

[20]. Tomberlin JK, Wallace JR, Olson J (2006) Forensic Entomology: History and Application of Entomology in Forensic Investigations, AgriLife Extension, Texas.
[21]. Krikken J, Huijbregts J (2001) Insects as forensic informants: the Dutch experience and procedure. Proceedings of the Section Experimental and Applied Entomology 12:159-164.

[22]. Keshavarzi D, Fereidooni M, Assareh M, Nasiri Z (2015) A checklist of forensic important flies (Insecta:Diptera) associated with indoor rat carrion in Iran. Journal of Entomology and Zoology Studies 3(3):140-142.

[23]. Kokdener M, Polat E (2014) Insect succession on dog (Canis lupus familiaris L.) carcasses in Samsun province, Turkey. Munis Entomology \& Zoology 9(2):858-869.

[24]. Vitta A, Pumidonming W, Tangchaisuriya U, Poodendean C, Nateeworanart S (2007) A preliminary study on insects associated with pig (Sus scrofa) carcasses in Phitsanulok, northern Thailand. Tropical biomedicine 24(2):15.

[25]. Watson-Horzelski EJ (2012) Survival and Time of Development for Creophilus maxillosus (L.) (Coleoptera: Staphylinidae) at three constant temperatures. The Coleopterists Bulletin 66(4):365-370.

[26]. Kramer S (1955) Notes and observations on the biology and rearing of Creophilus maxillosus (L.) (Coleoptera, Staphylinidae). Annals of Entomological Society of America 48(5):375-380.

[27]. Birch LC (1953) Experimental background to the study of the distribution and abundance of insects: I. The influence of temperature, moisture and food on the innate capacity for increase of three grain beetles. Ecology 34:698-711. 